Textos 



\title{
História da mentira:
} prolegômenos

\author{
JACQUES DERRIDA
}

A NTES MESMO DE PROPOR UMA EPÍGRAFE, solicito-lhes o tempo para duas confissões, que são também duas concessões. Dizem respeito à fábula e ao fantasma, ou seja, ao espectral. Como se sabe, em grego, phántasma significa também aparição do espectro: fantasma ou alma de outro mundo. $\mathrm{O}$ fabuloso e o fantasmático têm um traço em comum: stricto sensu e no sentido clássico desses termos, eles não pertencem nem ao verdadeiro nem ao falso, nem ao veraz nem ao mentiroso. Antes, assemelham-se a uma espécie irredutível do simulacro ou da virtualidade. É certo que não constituem verdades ou enunciados verdadeiros propriamente ditos; tampouco são erros, enganos propositados, falsos testemunhos ou perjúrios.

A primeira confissão concedida diz respeito ao título proposto: História da mentira. Deslocando-o ligeiramente, introduzindo uma palavra por sob a outra, ele parece imitar o célebre título de um texto que, há tempos, me interessou muito. Em o Crepúsculo dos Ídolos, Nietzsche intitula "História de um erro" (Geschichte eines Irrtums) a uma espécie de narrativa em seis episódios que, em uma página apenas, conta nada menos do que o mundo verdadeiro (die wahre Welt), a história do "mundo verdadeiro". O título dessa narrativa de ficção anuncia a de uma afabulação: "Como o 'mundo verdadeiro' acaba se tornando uma fábula (Wie die 'wahre Welt' endlich zur Fabel wurde)". Então, o que nos vai ser contado não é uma fábula, mas como uma fábula, de alguma forma, se afabulou. Vai se proceder como se houvesse a possibilidade de uma narrativa verdadeira a respeito da história dessa afabulação, e de uma afabulação que nada produz senão, precisamente, a idéia de um mundo verdadeiro - o que ameaça acabar com a pretensa verdade da narrativa. "Como o 'mundo verdadeiro' acaba se tornando uma fábula (Wie die 'wahre Welt' endlich zur Fabel wurde)". "História de um erro" é apenas subtítulo. Tal narrativa fabulosa sobre uma fabulação, sobre a verdade como afabulação é um lance teatral. Ela põe em cena personagens que ficarão, com mais ou menos intensidade, presentes a nós, ao modo de espectros, nos bastidores: primeiro, Platão, que diz, segundo Nietzsche, "Eu, Platão, sou a verdade", depois a promessa cristã sob os traços de uma mulher, depois o imperativo kantiano, a "pálida idéia könisbergiana", depois o canto do galo positivista, enfim o meio-dia zaratustriano. Além de tornar a citar tais espectros, referir-nos-emos 
também a outro, que Nietzsche não menciona: Santo Agostinho. É verdade que este, em seus grandes tratados sobre a mentira (De mendacio ou Contra mendacium) fica sempre dialogando com São Paulo, o qual, íntimo de Nietzsche, foi o adversário privilegiado de um Nietzsche obstinado.

Todavia, se a lembrança do texto fabuloso não deve ser por nós esquecida, a história da mentira não poderia ser a história de um erro, ainda que fosse um erro na constituição do verdadeiro, na própria história da verdade como tal. No texto polêmico e irônico de Nietzsche, nessa inspirada fábula sobre uma afabulação, a verdade, a idéia de um mundo verdadeiro seria um erro.

Em princípio, porém, e em sua determinação clássica, a mentira não é o erro. Pode-se estar no erro, enganar a si mesmo sem intenção de enganar os outros e, portanto, sem mentir. É verdade que mentir, enganar e enganar a si mesmo se inscrevem igualmente na categoria do pseudológico. Pseudos, em grego, pode significar a mentira tanto quanto a falsidade, o ardil ou o erro, o engano propositado, a fraude, assim como a invenção poética, o que multiplica os mal-entendidos sobre o que o mal-entendido pode significar - e isso não simplifica a interpretação de um diálogo refutativo tão denso e agudo quanto o Hippias menor (é peri tou pseudous anatreptikos). É verdade também que Nietzsche parece suspeitar o platonismo ou o cristianismo, o kantismo e o positivismo de terem mentido ao tentar nos induzir a acreditar no mundo verdadeiro. Mentir não é enganar-se nem cometer erro; não se mente dizendo apenas o falso, pelo menos se é de boa fé que se crê na verdade daquilo que se pensa ou daquilo acerca do que se opina no momento. É o que lembra Santo Agostinho na abertura de seu De mendacio (1) no qual, aliás, propõe uma distinção entre crença e opinião que poderia ser para nós, ainda hoje, hoje de forma nova, de grande alcance. Mentir é querer enganar o outro, às vezes até dizendo a verdade. Pode-se dizer o falso sem mentir, mas pode-se dizer o verdadeiro no intuito de enganar, ou seja, mentindo. Mas não mente quem acredita naquilo que diz, mesmo que isto seja falso. Ao declarar: "Quem enuncia um fato que lhe parece digno de crença ou acerca do qual formava opinião de que é verdadeiro, não mente, mesmo que o fato seja falso", Santo Agostinho parece excluir a mentira a si mesmo, e aqui está uma pergunta que não nos deixará jamais: será que é possível mentir a si mesmo, será que qualquer forma de enganar a si mesmo, de usar de subterfúgio para consigo merece o nome de mentira?

Teremos dificuldade em acreditar que a mentira tem uma história. A história da mentira, quem ousaria contá-la? E quem a prometeria como uma história verdadeira? Pois mesmo supondo-se, concesso non dato, que a mentira tivesse uma história, ainda assim seria preciso contá-la sem mentir. E sem ceder com exagerada facilidade a um esquema convencional e dialético que faria com que a história do erro, como história e trabalho do negativo, contribuísse ao processo 
da verdade, à verificação da verdade, com vistas ao saber absoluto. Se é que existe uma história da mentira, isto é, do falso testemunho, se é que toca em alguma radicalidade do mal chamado mentira ou perjúrio, ela não poderia se deixar apropriar por uma história do erro ou da verdade. Por outro lado, se a mentira supõe, ao que parece, a invenção deliberada de uma ficção, nem toda ficção ou fábula equivale a uma mentira; tampouco a literatura. Pode-se, desde já, imaginar mil e uma histórias fictícias da mentira, mil e um discursos inventivos, fadados ao simulacro, à fábula, à produção de formas novas referentes à mentira e que nem por isso sejam histórias mentirosas, isto é, se adotarmos o conceito clássico e dominante da mentira, histórias que não sejam perjúrios e falsos testemunhos.

Por que invocar aqui um conceito clássico e dominante da mentira? Haveria, em estado prático e teórico, um conceito prevalente da mentira em nossa cultura? E por que lembrar desde já os seus traços? Esses traços, eu os formalizarei, à minha maneira, esperando que esta seja verdadeira, justa e adequada - pois a coisa não é tão simples e, se eu me engano, só poderá ser mentira se eu tiver feito de propósito. Será difícil - ouso dizer até impossível - provar que o fiz de propósito. Tal observação visa apenas a anunciar desde já uma hipótese: por razões estruturais, será sempre impossível provar, em sentido estrito, que alguém mentiu, mesmo se podendo provar que não disse a verdade. Não se poderá nunca provar contra alguém que afirmar "eu me enganei, mas não quis enganar a ninguém, sou de boa fé”, ou ainda, alegando a diferença sempre possível entre o dito, o dizer e o querer-dizer, os efeitos da língua, da retórica, do contexto "eu disse isso, mas não é o que queria dizer; de boa fé, em meu foro íntimo, essa não era minha intenção, houve mal-entendido".

Eis agora, então, tal como creio que a devo formular aqui, uma definição da definição tradicional da mentira. Na sua figura prevalente e reconhecida por todos, a mentira não é um fato ou um estado, é um ato intencional, um mentir - não existe a mentira, há este dizer ou este querer-dizer que se chama mentir: mentir seria dirigir a outrem (pois não se mente senão ao outro, não se pode mentir a si mesmo, a não ser a si mesmo enquanto outro) um ou mais de um enunciado, uma série de enunciados (constativos ou performativos) cujo mentiroso sabe, em consciência, em consciência explícita, temática, atual, que eles formam asserções total ou parcialmente falsas; é preciso insistir desde já nessa pluralidade e complexidade, até mesmo heterogeneidade. Tais atos intencionais são destinados ao outro, a outro ou outros, a fim de enganá-los, de levá-los a crer (a noção de crença é aqui irredutível, mesmo que permaneça obscura) naquilo que é dito, numa situação em que o mentiroso, seja por compromisso explícito, por juramento ou promessa implícita, deu a entender que diz toda a verdade e somente a verdade.

O que conta aqui, em primeiro e último lugar, é a intenção. Santo Agostinho 
assinalava também: "não há mentira, apesar do que se diz, sem intenção, desejo ou vontade de enganar" (fallendi cupiditas, voluntas fallendi) (2). Tal intenção, que define a veracidade ou a mentira na ordem do dizer, do ato de dizer, permanece independente da verdade ou da falsidade do conteúdo, daquilo que é dito. A mentira depende do dizer e do querer-dizer, não do dito “... não se mente ao enunciar uma asserção falsa que cremos verdadeira e (...) antes mente-se ao enunciar uma asserção verdadeira que cremos falsa. Pois é pela intenção (ex animi sui) que se deve julgar a modalidade dos atos" (3).

Tal definição parece a um só tempo evidente e complexa. Precisaremos de cada um de seus elementos em nossa análise. Se insisti no fato de que tal definição da mentira encerrava um conceito prevalente em nossa cultura, foi para dar uma chance à hipótese de que esse conceito, determinado por uma cultura, por uma tradição religiosa ou moral, talvez por mais de uma herança, por uma multiplicidade de línguas etc., tinha ele próprio uma história. Assim, apresentase uma primeira e depois uma segunda complicação: se o conceito aparentemente mais comum da mentira, se o bom senso quanto à mentira, tem uma história, ele se acha então inserido num vir-a-ser que expõe sempre ao risco de lhe relativizar a autoridade e o valor. Mas - segunda complicação - é preciso distinguir entre a história do conceito de mentira e a história da própria mentira, uma história e uma cultura que influem na prática da mentira, formas, motivações, técnicas, vias e efeitos da mentira. Mesmo dentro de uma única cultura, em que reinasse com exclusividade um conceito estável da mentira, a experiência social, a interpretação, a prática do mentir podem mudar, resultando em outra historicidade, em historicidade interna da mentira. Supondo-se que dispuséssemos em nossa tradição, chamada ocidental (judia, grega, romana, cristã, islâmica), de um conceito unificado, estabilizado e, portanto, confiável da mentira, não bastaria the reconhecer uma historicidade intrinsecamente teórica, ou seja, aquilo que o distinguiria de outros conceitos em outras histórias e culturas; seria também necessário examinar a hipótese de uma historicidade prática, social, política, tecnológica que o teria transformado, até marcado, por rupturas dentro de nossa tradição.

É a essa última hipótese que eu gostaria de conceder algum privilégio provisório. Mas será que algum dia se tornará possível distinguir entre

- uma história (Historie) do conceito de mentira;

- uma história (Geschichte) da mentira, feita de todos os acontecimentos que se deram com a mentira ou pela mentira;

- uma história verdadeira que ordena a narrativa (Historie, historia rerum gestarum) dessas mentiras ou da mentira em geral?

Como dissociar ou alternar as três tarefas? Não nos esqueçamos jamais dessa dificuldade. 
Antes mesmo de chegar às epígrafes, antes mesmo de começar a começar, devo fazer uma segunda confissão. Teriam todos o direito de desconfiar dela, como de qualquer confissão. Em razão de vários tipos de limites, particularmente dos limites de tempo estritamente fixados, não direi tudo nem mesmo o essencial daquilo que posso pensar a respeito de uma história da mentira. O fato de eu não dizer toda a verdade sobre uma história da mentira não surpreenderá ninguém: tampouco direi toda a verdade sobre aquilo que eu mesmo posso pensar ou testemunhar, hoje, sobre uma história da mentira e a maneira, totalmente diferente, pela qual seria necessário, na minha opinião, escutar ou contar tal história. Não direi, portanto, toda a verdade daquilo que eu penso. Meu testemunho será parcial. Terei culpabilidade nisso? Significará que eu lhes menti? Deixo esta questão suspensa, pelo menos até o momento da discussão, e, provavelmente, para além dela.

Duas citações fragmentárias deverão agora, como epígrafe, velar sobre esses prolegômenos. Darei, em primeiro lugar, a palavra a dois pensadores cuja memória - que habita esta casa - cabe saudar.

Longe de se limitar a contar certa história, cada um desses fragmentos reflete no seu brilho uma historicidade paradoxal e insólita.

Historicidade da mentira, em primeiro lugar. O fato de que a política é um lugar privilegiado para a mentira é bem conhecido. Hannah Arendt o lembra mais de uma vez: "As mentiras sempre foram consideradas instrumentos necessários e legítimos, não somente do ofício do político ou do demagogo, mas também do estadista. Por que será assim? $\mathrm{O}$ que isso significa quanto à natureza e dignidade do campo político por um lado, quanto à natureza e dignidade da verdade e da boa fé por outro lado?” (4).

Assim é que se abre "Vérité et politique" (Truth and politics), cuja primeira versão inglesa, em 1967, foi um artigo publicado na revista New Yorker para responder a uma polêmica jornalística consecutiva à publicação de Eichmann em Jerusalém. Todos sabem que Hannah Arendt, a seu modo, se deu a missão de jornalista no processo Eichmann. Depois, denunciou grande número de mentiras e falsificações concernentes a ela mesma, pelas quais a imprensa era a principal responsável. Lembra esse contexto na primeira nota de Truth and politics, destacando assim um efeito da mídia, e o faz num grande jornal, o New Yorker. Saliento imediatamente a dimensão proporcionada pela mídia, os locais de publicação e os títulos de jornais tanto nova-iorquinos como internacionais, por razões que, espero, irão se esclarecendo. Foi em New Review of Books da época (pois este jornal também tem uma história e Hannah Arendt escreveu nele freqüentemente) que publicou alguns anos mais tarde, em 1971, "Mentir em política: reflexões sobre os Pentagon Papers" (Lying in politics: reflexions on the Pentagon Papers). Quanto aos Pentagon Papers, documentos secretos patrocinados por McNamara 
sobre a política americana no Vietnã, desde a Segunda Guerra Mundial até 1963, tinham sido publicados por outro jornal, também nova-iorquino e internacional, o New York Times. Falando daquilo que estava "na cabeça dos que coletaram os Pentagon Papers para o New York Times" (in the mind of those who compiled The Pentagon Papers for the New York Times), Hannah Arendt observa: "A famosa falha de credibilidade, que conhecemos durante seis longos anos, abriu-se subitamente para um abismo. As areias movediças das declarações mentirosas de todo tipo: o enganar e o enganar a si mesmo (deception as well as self-deceptions: ressalto self-deceptions que vai designar mais tarde um de nossos problemas. Será mesmo possível a self-deception ? Será um conceito rigoroso e pertinente para aquilo que aqui nos interessa, ou seja, a história da mentira? Será rigorosamente possível mentir a si mesmo?) estavam prontas para tragar todos os leitores preocupados em pôr à prova esse material que, infelizmente, deveriam reconhecer como a infra-estrutura de cerca de uma década de política externa e interna dos Estados Unidos" (The famous credibility gap, which has been with us for six long years, has suddenly opened up into an abyss. The quicksand of lying statements of all sorts, deceptions as well as self-deceptions, is apt to engulf any reader who whishes to probe this material, which, unhappily, he must recognize as the infrastructure of nearly a decade of United States foreign and domestic policy) (5).

Se a história, e particularmente a história política, está repleta de mentiras, como bem se sabe, como a própria mentira poderia ter uma história? Como a mentira, cuja experiência é tão comum, a estrutura aparentemente tão evidente, a possibilidade universal tanto quanto intemporal, como poderia ela ter uma história que lhe seja intrínseca e essencial? Ora, eis que Hannah Arendt, sempre em Truth and politics, chama nossa atenção para uma mutação na história da mentira. Tal mutação estaria em ação ao mesmo tempo na história do conceito e da prática do mentir. Apenas em nossa modernidade é que a mentira teria alcançado seu limite absoluto e teria se tornado "completa e definitiva". Ascensão e triunfo da mentira: enquanto, nas Artes e nas Letras, Oscar Wilde se queixara antigamente daquilo que chamou - o título se tornaria célebre - $O$ declínio da mentira (The decay of lying), Arendt, ao oposto, diagnostica um crescimento hiperbólico da mentira no campo político, que teria chegado a seu limite, ou seja, à mentira absoluta, não se tratando no caso do saber absoluto como fim da história, mas da história como conversão à mentira absoluta. Como entender isso? "A possibilidade da mentira completa e definitiva, que era desconhecida em épocas anteriores, é o perigo que nasce da manipulação moderna dos fatos. Mesmo no mundo livre, em que o governo não monopolizou o poder de decidir ou de dizer aquilo que é ou não factualmente, gigantescas organizações de interesses generalizaram uma espécie de mentalidade da raison d'Etat (em francês no texto) que antes estava limitada ao tratamento dos negócios estrangeiros, e em 
seus piores excessos, às situações de perigo claro e atual. A propaganda, em nível governamental, inspirou-se sob vários aspectos nos usos do business e métodos de Madison Avenue ..."(6).

Seria tentador, porém um pouco fácil demais, opor, como dois fins da História, o conceito negativo deste mal, a mentira absoluta, à positividade do saber absoluto - seja em modo maior (Hegel), seja em modo menor (Fukuyama). O que deveria, provavelmente, ser suspeitado com alguma inquietude nesta noção de mentira absoluta, é aquilo que ela supõe ainda de saber absoluto num elemento que permanece o da consciência de si reflexiva. Por definição, o mentiroso sabe a verdade - se não toda a verdade, pelo menos a verdade daquilo que pensa, sabe o que ele quer dizer, sabe a diferença entre aquilo que pensa e aquilo que diz: sabe que mente. Tal laço de essência entre saber, ciência, consciência de si e mentira, Sócrates já ensinava e utilizava em outro texto maior de nossa tradição concernente à mentira, o Hippias menor (é operi tou pseudous). Se a mentira absoluta tem de se exercer em consciência e no seu conceito, ela corre o risco de continuar sendo a outra face do saber absoluto.

Em outra parte do mesmo artigo, dois exemplos tirados da política européia colocam novamente em cena mentiras de tipo moderno. Desta vez, os atores seriam De Gaulle e Adenauer. Proclamava o primeiro - e quase acabou convencendo - que "a França fazia parte dos vencedores da última guerra, sendo ela, portanto, uma das grandes potências"; para o segundo "a barbárie do nacional-socialismo só havia afetado uma percentagem relativamente baixa do país" (7). Tais exemplos encontram-se rodeados por fórmulas que opõem ainda a mentira política tradicional à reescritura moderna da História e insistem num novo estatuto da imagem: "Devemos agora voltar a nossa atenção para o fenômeno, relativamente recente, da manipulação de massa, do fato e da opinião, tal como se tornou evidente na reescritura da história, na construção de imagens e na política dos governos. A mentira política tradicional, tão manifesta na história da diplomacia e da habilidade política, referia-se habitualmente a autênticos segredos - dados que nunca haviam sido tornados públicos - ou então a intenções que, de qualquer maneira, não possuem o mesmo grau de certeza que os fatos consumados (...) as mentiras políticas modernas tratam de forma eficiente coisas que não são segredos de forma alguma, praticamente conhecidas por todos. Isso é evidente no caso da reescritura da História contemporânea, sob os olhos daqueles que dela foram testemunhas, mas é verdade também na falsificação de imagens de todo tipo (...) pois uma imagem, à diferença de um retrato ao modo antigo, não tem apenas o papel de idealizar a realidade, mas de substituí-la por completo. Tal substituto, por causa das tecnologias modernas e da mídia, destaca-se, evidentemente, mais do que o original" (We must now turn our attention to the relatively recent phenomenon of mass manipulation of fact and opinion as it has become evident in rewriting history, in image-making, and in actual government policy. 
The traditional political lie, so prominent in the history of diplomacy and statecraft, used to concern either true secrets - data that had never been made public - or intentions, which anyhow do not possess the same degree of reliability as accomplished facts. (...) This is obvious in the case of rewriting contemporary history under the eyes of those who witnessed it, but it is equally true in imagemaking of all sorts (...) In contrast, the modern political lies deal efficiently with things that are not secrets at all but are known to practically everybody).

É a razão por que, já que a imagem-substituto não remete doravante ao original nem mesmo a um original representado de forma lisonjeira, mas o substitui com vantagem, passando do estatuto de representante ao de substituto, o processo da mentira moderna já não seria a dissimulação que veio encobrir a verdade, mas a destruição da realidade ou do arquivo original: "Em outros termos, a diferença entre a mentira tradicional e a moderna equivale, no mais das vezes, à diferença entre esconder e destruir" (In other words, the difference between the traditional lie and the modern lie will more often than not amount to the difference between hiding and destroying) (8).

Teremos de aprofundar, mais adiante, a lógica de tais proposições. Será que a palavra e o conceito de mentira, se levarmos em conta precisamente sua história conceitual, são apropriados para designar os fenômenos à nossa modernidade política, tecno-mediática, testemunhal, para os quais Hannah Arendt tão cedo e tão lucidamente orientou nossa atenção - e freqüentemente por a ter experimentado, ela própria, do modo mais doloroso, em especial quando foi ser repórter no decorrer do processo Eichman?

Eis, agora a outra epígrafe, de Reiner Schürmann. A historicidade, que ele cita também, seria a de certa sacralidade ou santidade. Tal sacro-santidade (Heiligkeit) é constitutiva, por exemplo, na opinião de Kant e numa tradição augustiniana que ele não declara explicitamente, do dever ou do imperativo incondicional de não mentir. $\mathrm{O}$ dever de dizer a verdade é um imperativo sagrado. Schürmann observa em Le principe d'anarchie e numa leitura de Heidegger: "Uma vez que a noção de sagrado pertence ao contexto do original, ela permanece histórica: o sagrado é 'o vestígio dos deuses desaparecidos' que conduz para seu retorno (diz Heidegger em os Holzwege, p. 250 e ss.). Ao oposto, o pudor e a piedade, por acompanharem o fenômeno do originário, orientam tão somente o pensamento para o despertar da presença, o que não é de forma alguma histórico" (9).

Agora tentarei começar, e sem mentir, acreditem em mim, por contar algumas histórias. Num modo aparentemente narrativo, o de um historiador ou de um cronista clássico, eu thes proporia alguns exemplos particulares a partir 
dos quais procuraríamos progredir de uma forma reflexionante, por analogia com aquilo que Kant talvez tivesse dito sobre o juízo reflexivo. Iríamos assim do particular ao geral, para refletir e não para determinar e para refletir visando a um princípio que não poderia ser dado pela experiência. Se eu me refiro desde já, ao menos por analogia, à grande e canônica distinção kantiana entre juízos determinantes e juízos reflexivos, é por três razões: Por um lado, tal distinção ocasiona na Crítica do juízo antinomias e uma dialética que provavelmente não sejam alheias àquelas nas quais não tardaremos a nos embaraçar; por outro lado, Hannah Arendt, sempre em "Verdade e política" (Truth and politics), lembra demoradamente a virtude do exemplo segundo Kant; cita aliás a Crítica do juizo; finalmente e sobretudo, Kant é também o autor de um ensaio breve, denso, difícil, escrito em forma de resposta polêmica a um filósofo francês, Benjamin Constant, e que constitui, a meu ver, na História do Ocidente, depois de Santo Agostinho, uma das mais radicais e poderosas tentativas para pensar a mentira, para determinar, refletir, proscrever ou proibir também toda e qualquer mentira. Incondicionalmente. Trata-se de texto curto de 1797, porém pouco lido e mal conhecido, que se intitula Sobre um suposto direito de mentir por humanidade (10). Hannah Arendt menciona muitas vezes Kant no artigo que acabei de evocar e em outra parte, porém nunca citando este ensaio, apesar de ele ser a um só tempo tão necessário e temível, até mesmo irredutível à lógica profunda daquilo que ela quer demonstrar. Sem ir tão longe quanto seria preciso na leitura do dito texto, podemos desde já levar rigorosamente em conta o modo pelo qual Kant define nele a mentira e o imperativo de veracidade ou veridicidade (pois, o contrário da mentira não é a verdade nem a realidade, mas a veracidade ou a veridicidade, o dizer verdadeiro, o querer-dizer verdadeiro, a Wahrhaftigkeit). A definição kantiana da mentira ou do dever de veracidade apresenta-se como tão formal, imperativo e incondicional, que parece excluir justamente qualquer consideração histórica, qualquer fator ligado a condições ou hipóteses históricas. Sem se debruçar, à maneira de um casuísta, sobre todos os casos difíceis e inquietantes analisados por Santo Agostinho, partindo no mais das vezes de exemplos bíblicos, Kant parece excluir todo conteúdo histórico quando define a veracidade (Wabrhaftigkeit: veracitas) como um dever formal absoluto: "A veracidade nas declarações é o dever formal (formale Pflicht) do homem com relação a cada um, por mais grave que seja o prejuízo que dela possa resultar”.

Embora seja o texto expressamente jurídico e não-ético, embora trate como o próprio título indica do direito de mentir (Recht... zu lügen), embora fale de dever de direito (Rechtspflicht) e não de dever ético, o que poderia à primeira vista parecer mais propício ou menos irredutível a um ponto de vista histórico, Kant, no entanto, na sua definição de mentira, parece excluir toda aquela historicidade que, ao contrário, Hannah Arendt introduz na própria essência, no acontecimento e desempenho da mentira. É que, se de fato esse ponto de vista de Kant 
permanece pura e formalmente jurídico ou metajurídico, ele corresponde ao cuidado com as condições formais do direito, do contrato social e da pura fonte do direito. "Assim, simplesmente definida como uma declaração deliberadamente não-verdadeira (unwahre Declaration) dirigida a outro homem, a mentira não precisa da cláusula segundo a qual ela deve causar prejuízo ao outro, cláusula exigida pelos juristas para sua definição (mendacium est falsiloquium in praejudicium alterius). Pois, ela sempre prejudica a outrem: mesmo não sendo a outro homem, é à humanidade em geral, já que desqualifica a fonte do direito (pondo-a fora de uso: die Rechtsquelle unbrauchbar macht)".

Kant pretende provavelmente definir aquilo que, na mentira, é mau a priori em si mesmo, na sua imanência, sejam quais forem as motivações e conseqüências. Mas a ele interessa, antes de tudo, a própria fonte do direito humano e da socialidade em geral, ou seja, a necessidade imanente de dizer o verdadeiro, quaisquer que sejam os efeitos esperados, os contextos externos e históricos. Se não se banir incondicionalmente a mentira, destrói-se o laço social da humanidade em seu próprio princípio. Nessa pura imanência é que reside a sacralidade ou santidade do mandamento racional de dizer o verdadeiro, de querer dizer o verdadeiro. Recentemente, Schürmann dizia que a sacralidade era histórica. Em outro sentido, parece que com Kant e neste caso ela não o seja, pelo menos no sentido comum. Mas permanece a hipótese de que o seja em outro sentido como origem e condição de uma história e de uma socialidade humana em geral. Kant, em todo caso, escreve: "Este é, portanto, o mandamento da razão (Vernunftgebot) que é sagrado (beiliges), incondicionalmente imperativo (unbedingt gebietendes), que não pode ser limitado por conveniência alguma: em qualquer declaração, é preciso ser verídico (Wahrhaft) (leal, sincero, honesto, de boa fé: ehrlich)".

Chego finalmente aos exemplos prometidos e às minhas crônicas dos dois mundos. Eu os escolho, de fato, o mais perto possível de nossos dois continentes: a Europa e a América (entre Paris e Nova York) e dos jornais New York Times e a edição parisiense de International Herald Tribune. Há alguns meses, o presidente Chirac, pouco depois de sua eleição, quando já havia anunciado como uma decisão irrevogável que a França iria retomar os testes nucleares no Pacífico - lembramonos disso - reconheceu solenemente, no dia do aniversário da blitz do Vel' d'Hiv *, de sinistra memória, a responsabilidade, ou seja, a culpabilidade do Estado francês durante a ocupação nazista na deportação de dezenas de milhares de judeus, na instauração de um estatuto dos judeus e em numerosas iniciativas que não foram tomadas apenas sob a coação do ocupante nazista. Tal culpabilidade, participa-

\footnotetext{
"Vel' d'Hiv: velódromo de inverno (hoje desativado), situado na $15^{a}$ Circunscrição administrativa de Paris. Blitz do Vel' d'Hiv: no dia 16 de julho de 1942, 4500 policiais franceses subordinados ao governo de Vichy tiravam de suas casas e levavam para o Vel' d'Hiv cerca de 13 mil judeus entre homens, mulheres e crianças, que posteriormente seriam deportados para a Alemanha, onde muitos iriam morrer em campos de extermínio. (N. Do T.)
} 
ção ativa naquilo que hoje configura-se como crime contra a humanidade, ei-la agora reconhecida. Irreversivelmente. Ei-la enfim confessada por um Estado como tal. A confissão foi selada por um chefe de Estado eleito pelo sufrágio universal. É declarada publicamente, em nome do Estado francês, diante da figura ou na cara do direito internacional, num ato teatral e amplamente divulgado no mundo inteiro pela mídia: imprensa escrita, radiofônica e televisiva (saliento mais uma vez a relação entre a res publica e a mídia por ser esse, junto com a mutação do estatuto da imagem, um de nossos temas). A verdade proclamada pelo presidente Chirac dali em diante tem o estatuto - a uma só vez a estabilidade e a autoridade - de uma verdade pública, nacional e internacional.

No entanto, essa verdade sobre uma história tem ela mesma uma história. Só chegou a ser legitimada, estabelecida como tal, mais de 50 anos após a ocorrência dos fatos. Seis presidentes da República francesa (Auriol, Coty, De Gaulle, Pompidou, Giscard d'Estaing, Mitterand) não haviam até então julgado possivel nem oportuno nem necessário nem mesmo justo estabilizá-la em verdade deste tipo. Nenhum deles acreditou que devesse empenhar a palavra da França, da nação francesa, da República francesa por uma espécie de assinatura que teria vindo assumir a responsabilidade dessa verdade: a França culpada de crime contra a humanidade. Poderíamos citar hoje inúmeros exemplos e situações semelhantes, desde o Japão até os Estados Unidos ou Israel, a respeito de violências ou repressões passadas, de crimes de guerra notórios ou recém-descobertos, do uso justificado ou não de bombas atômicas em Hiroshima (sabe-se que, apesar dos testemunhos de grandes historiadores, o presidente Clinton continua a considerar oficialmente o bombardeio de Hiroshima e Nagasaki como uma decisão justificada) sem falar daquilo que está em compasso de espera: política do Japão na Ásia durante a guerra, guerra da Argélia, guerra do Golfo, ex-Iugoslávia, Ruanda, Chechênia etc. Acabei de citar o Japão entre parênteses, e, justamente, no dia em que me preparava para esta conferência, o Primeiro Ministro Muruyama fazia uma declaração na qual todas as palavras e toda a estrutura pragmática precisariam ser ponderadas: sem engajar o Estado japonês na sua autoridade máxima e na permanência de sua identidade imperial na pessoa do imperador, um Primeiro Ministro fala. Diante daquilo que chama de modo significativo "esses fatos irrefutáveis da história" ( these irrefutable facts of history), para citar a tradução inglesa na qual eu li o discurso pela primeira vez, e um "erro em nossa história" (error in our history), Muruyama apresenta em seu nome (que significa mais do que o próprio nome, mas não envolve o nome do imperador) seu "pesar profundo e sincero" (heartfelt apology) e expressa seus sentimentos de luto; um luto ao mesmo tempo pessoal, vaga e confusamente nacional e estatal. O que será um luto de Estado quando se choram mortes que não são as de um chefe de Estado, nem mesmo de concidadãos? Como entender remorso ou desculpas estatais depois que o direito internacional definiu o crime contra a humanidade? 
Temos aí inúmeras perguntas que há 50 anos não haveria condição de formular. Continuo citando em inglês, conforme eu li, a declaração de Muruyama: "I regard, in a spirit of humility, these irrefutable facts of history, and express here once again my feelings of deep remorse and state my heartfelt apology ...”. Depois, ao evocar uma repressão "colonial" - o que deveria chamar a atenção de outros eximpérios coloniais - o Primeiro Ministro japonês acrescenta: "Allow me also to express my feelings of profound mourning for all victims, both at home and abroad, of that history”. Em sua confissão declara também a responsabilidade de uma tarefa e assume um compromisso para o futuro: "Our task is to convey to the younger generations the horrors of war, so that we never repeat the errors in our history”. Para amenizar o efeito, a linguagem da culpa e da confissão mistura-se com a linguagem heterogênea do erro; e eis que, talvez pela primeira vez na história, se ousa dissociar o conceito de Estado ou nação daquilo que sempre o caracterizou de forma constitutiva e estrutural, ou seja, a boa consciência. Por mais confuso que seja o acontecimento, por mais impura que permaneça sua motivação, por mais calculada e conjuntural que seja sua estratégia, cabe registrar aqui um progresso na história da humanidade e de seu direito internacional, de sua ciência e e de sua consciência. Kant talvez teria identificado nessa confissão um desses acontecimentos que representam um sinal, sinal que, como a Revolução Francesa, por exemplo, através do fracasso ou do limite rememora, demonstra e anuncia (signum rememorativum, demonstrativum, prognosticum), atestando assim uma tendência e a possibilidade de progresso para a humanidade (tudo isso continua parcial para o Japão, a França, a Alemanha, mas é melhor do que nada: a União Soviética ou a Iugoslávia, que já não existem, ficam livres de qualquer má consciência e do reconhecimento público dos crimes passados; os Estados Unidos têm todo o futuro à sua frente; fecho o parêntese e volto para a minha terra).

O fato de que, durante meio-século, nenhum chefe de Estado francês tenha julgado possível, oportuno, necessário ou justo constituir em verdade uma imensa culpabilidade francesa, reconhecê-la como verdade, já permite entender que em tal caso o valor da verdade, isto é, da veracidade, o valor de um enunciado a respeito de fatos reais (pois a verdade não é a realidade, mas antes de tudo o valor de um enunciado em conformidade com aquilo que pensamos) poderia depender de uma interpretação política no tocante a valores, heterogêneos aliás (possibilidade, oportunidade, necessidade, justeza ou justiça). A verdade ou a veracidade estariam a princípio subordinadas a esses valores: imenso problema, como sabem, problema clássico sem dúvida, mas para o qual talvez seja preciso encontrar alguma especificidade histórica, política, ligada atualmente à tecnomídia. Entre os presidentes anteriores, o próprio De Gaulle, a quem no entanto Chirac diz dever toda sua inspiração política, nunca pensou em declarar a culpabilidade do Estado francês sob a ocupação alemã, quando - ou então porque - a culpabi- 
lidade do Estado francês (era, aliás, o nome oficial da França sob o regime de Vichy; tendo sido abolida a República, foi rebatizada como Estado francês) permanecia, a seu ver, a de um Estado não-legítimo, se não ilegal. Pensemos também no caso de Vincent Auriol, outro dos presidentes que não achou possível, oportuno, ou justo, reconhecer o que Chirac acabou de reconhecer - e de reconhecer por razões conjunturais aparentemente mais complexas do que a simples obediência incondicional ao mandamento sagrado de que fala Kant. Vincent Auriol foi um dos 80 parlamentares, os únicos, que se recusaram a votar os plenos poderes para o Marechal Pétain em 10 de julho de 1940. Ele sabia, infelizmente, que a interrupção da República e a passagem desta para o Estado francês responsável pelo estatuto e pela deportação dos judeus foi um ato legal comprometendo o governo da França. A descontinuidade provocada pela interrupção foi, ela própria, inscrita na continuidade legal da República e do Estado francês. Foi a República francesa que, pelo voto de seus representantes legalmente eleitos, renunciou ao seu próprio estatuto. Essa, pelo menos, é a verdade da legalidade formal e jurídica. Mas onde está essa verdade, se é que existe tal verdade? Várias vezes e até o fim de seu mandato, François Mitterand recusou-se a reconhecer a culpabilidade oficial do Estado francês. Alegava explicitamente que o dito Estado francês se instalara por usurpação ao interromper a história da República francesa, única entidade política ou moral que teria autoridade para prestar contas nesse caso e se achava, na época, amordaçada ou na resistência ilegal. A República francesa, hoje, não tinha nada, na opinião dele, a "confessar", não tinha obrigação de assumir a memória e a culpabilidade de um tempo em que havia sido "descartada". A nação francesa, enquanto tal e na sua continuidade, não tinha por que se acusar de crimes contra a humanidade cometidos injustamente em seu nome. Embora tivesse inaugurado as comemorações públicas e solenes da blitz do Vel d'Hiv, Mitterand recusou tal reconhecimento apesar do grande número de pessoas que, durante anos, por meio de cartas ou abaixoassinados oficiais - que conheço por tê-los assinado -, pediam-lhe insistentemente que fizesse o que o presidente Chirac acabou felizmente de fazer.

Citarei ainda outra posição típica sobre esse problema, a de Jean-Pierre Chevènement, ex-ministro de Mitterand, socialista muito independente, oposto ao modelo europeu em vias de constituição, preocupado com soberania e honra nacional, o qual se demitiu do cargo de ministro da Defesa durante a guerra do Golfo. Para Chevènement, se é verdade que Chirac fez bem ao reconhecer a culpabilidade incontestável do Estado francês, por outro lado as conseqüências de tal "veracidade" e dos termos em que foi concretizada fazem correr graves riscos, por exemplo, o de legitimar a volta do petainismo, encorajando as forças que hoje precisariam difundir a idéia de que "Pétain é a França" * (11). Era também esse, ao que tudo indica, o ponto de vista do próprio general De Gaulle e, talvez, de forma menos determinada, dos presidentes que lhe sucederam. Em 
suma, verdade e veracidade certamente são necessárias; não se deve porém, pôlas em prática de qualquer modo, a qualquer preço. Nem todas as verdades devem ser ditas, como lembra um provérbio francês, e o imperativo não é tão sagrado, incondicional como o queria Kant. Seria preciso levar em conta imperativos hipotéticos, oportunidade pragmática do momento, formas do enunciado, da retórica, do destinatário etc. Para distinguir entre a legalidade do governo de Vichy e a vontade popular que se demitiu diante dele, Chevènement teve aliás de retroceder no tempo, pelo menos cinco anos, para determinar as reponsabilidades reais. Juridicamente, a análise propriamente histórica seria infinita e a distinção entre mentira e veracidade correria o risco de perder o rigor de suas arestas.

Eis então uma primeira série de perguntas: ao não declararem oficialmente o que é agora verdade histórica de Estado, os presidentes anteriores, desde De Gaulle até Mitterand, estariam eles mentindo ou dissimulando? Temos o direito de dizer isto? Poderiam eles, por sua vez, invertendo os papéis, acusar Chirac de mentir? Será que eles - uns ou outros - mentem? Quem mentiu e quem disse a verdade? Pode-se falar aqui de mentira? Será a mentira um conceito pertinente? Caso seja, qual seria o critério da mentira? O que seria a história de tal mentira? E sobretudo, pergunta ainda diferente, qual seria a história do conceito de mentira que levantaria perguntas como essas? Se houvesse aqui mentira, e fosse pertinente determinar isso ou aquilo como mentira, quem seria o sujeito e quem seria o destinatário ou a vítima? Naturalmente, voltarei a examinar a formação e formulação dessa primeira série de perguntas, mas gostaria, sempre a título preliminar, de ressaltar nesse exemplo dois traços originais.

Por um lado, existe de fato uma novidade histórica referente a tal situação na pragmática da oposição veracidade/mentira, se não na essência da mentira. É que aqui se trata de uma veracidade ou de uma mentira de Estado, determináveis como tais numa cena do direito internacional, que não existia antes da Segunda Guerra Mundial. Tais hipóteses são levantadas hoje por referência a conceitos jurídicos como o de crime contra a humanidade, que são invenções e, portanto performativos, não conhecidos pela humanidade até agora enquanto conceitos jurídicos que implicam jurisdições internacionais, contratos e cartas magnas interestatais, instituições e cortes de justiça em princípio universais. Se tudo isso é histórico por inteiro, a problemática da mentira ou da confissão - o imperativo da veracidade a respeito de algo como um crime contra a humanidade - não tinha sentido algum nem para indivíduos nem para o Estado antes da definição deste conceito jurídico no artigo $6 \mathrm{c}$ dos Estatutos do Tribunal militar internacional de Nuremberg e sobretudo, pelo menos em se tratando da França, se não

\footnotetext{
* Pétain é a França, frase tirada do Hino ao Marechal, muito divulgado nos primeiros tempos do Estado Francês em escolas e em concentrações esportivas, pela rádio etc. Foi o lema do regime. (N. DO T.)
} 
me engano, antes que esses crimes tivessem sido declarados imprescritiveis por uma lei de 26 de dezembro de 1964.

Por outro lado, os objetos em questão, aqueles a respeito dos quais teríamos de nos pronunciar, não constituem realidades naturais em si. Dependem de interpretações, mas também de interpretações performativas. Não estou falando aqui do ato de linguagem performativo pelo qual, ao confessar uma culpabilidade, um chefe de Estado produz um acontecimento e provoca uma reinterpretação de todas as linguagens de seus predecessores. Não se trata disso. Quero salientar, antes de tudo, a performatividade operante nos próprios objetos das declarações: a legitimidade de um Estado supostamente soberano, a posição de uma fronteira, a identificação ou atestação de uma responsabilidade são atos performativos. Quando os performativos têm sucesso, produzem uma verdade cujo poder se impõe às vezes para sempre: a posição de uma fronteira, a instauração de um Estado são sempre violências performativas que, se as condições da comunidade internacional o permitem, criam o direito, duravelmente ou não, onde não existia ou deixara de existir, onde não era ou deixara de ser forte. Ao criar o direito, a violência performativa - a qual não é legal nem ilegal - cria em seguida o que é tido por verdade de direito, verdade pública dominante e juridicamente incontestável. Onde se encontra hoje a verdade concernente às fronteiras na ex-Iugoslávia, em todos os encraves clivados ou encravados em outros encraves, e na Chechênia, em Israel? Quem diz a verdade e quem mente nessas matérias? Para o melhor e o pior, a dimensão performativa faz a verdade, como diz Agostinho. Imprime, portanto, sua dimensão irredutivelmente histórica à veracidade tanto quanto à mentira.

Parece-me que tal poder performativo original não é levado tematicamente em conta nem por Kant nem Hannah Arendt. Tentarei mostrar que, apesar de tudo o que os separa ou opõe de outro ponto de vista, ambos, por ignorarem a dimensão sintomal ou inconsciente desses fenômenos, têm deles certo desconhecimento ou, em todo caso, uma explicitação insuficiente. Tais fenômenos não poderiam ser estudados, para dizer o mínimo, sem a conjugação de uma lógica do inconsciente e de uma teoria do performativo. O que não quer dizer que o discurso presente e atualmente elaborado da psicanálise ou da teoria dos speech acts seja suficiente para tanto. Tampouco significa que esteja pronta a articulação entre esses dois discursos - ou entre eles e um discurso sobre a política ou a economia dos saberes e poderes teletecnológicos. Estamos aqui definindo uma tarefa e as condições de uma análise que enfrenta esses fenômenos de nosso tempo.

Para ilustrar o que pode haver de temível nesse poder perfomativo em nossa modernidade teletecnológica da mídia, eis agora outra seqüência aparentemente menor da mesma história. Já disse que a mídia iria ocupar um lugar 
central nessa análise. O New York Times fez questão de relatar a recente declaração de Chirac. Suponhamos que preocupado com a verdade e a competência, o jornal entregou a responsabilidade do artigo a um professor universitário. Em nossa cultura, a idéia de competência está associada à Universidade e aos professores universitários. Segundo se supõe, os professores sabem e dizem o verdadeiro. O professor em questão, que supostamente sabe, leciona numa grande universidade nova-iorquina. É tido até por um perito nas coisas francesas da modernidade, na confluência da filosofia, da ideologia, da política e da literatura. O New York Times lembra que ele é o autor de um livro intitulado Past imperfect: French intellectuals, 1944 to 1956. Com o título de French war stories, em sua edição de 19 de julho de 1995 o jornal publica um artigo de Tony Judt, professor na New York University. Antes de concluir que "It is well that Mr. Chirac has told the truth about the French past" havia, porém, denunciado o comportamento vergonhoso dos intelectuais franceses, os quais, durante meio-século, haviam se preocupado tão pouco com essa verdade e seu reconhecimento público. Observa primeiro que Sartre e Foucault tinham sido a esse respeito curiously silent. E atribui tal atitude à simpatia deles pelo marxismo. A explicação proposta provoca a vontade de sorrir, em especial no caso de Foucault, quando se sabe que a maioria, os mais duráveis e conhecidos de seus engajamentos políticos não tinham absolutamente nada de marxistas, quando não eram expressamente antimarxistas. O que o professor Judt escreve em seguida, citarei apenas para, como introdução, multiplicar os exemplos de falhas que serão sempre difíceis de ser determinadas. Haveremos sempre de hesitar entre várias possibilidades. De que se trata exatamente? Incompetência? Falta de lucidez ou acuidade analítica? Ignorância de boa fé? Erro acidental? Má fé crepuscular entre mentira e inconsciência? Compulsão e lógica do inconsciente? Falso testemunho caracterizado, perjúrio, mentira? É verdade que essas categorias são irredutíveis uma à outra, mas o que pensar das situações tão freqüentes em que, de fato e em verdade, elas se contaminam mutuamente e já não podem ser objeto de uma delimitação rigorosa? E se um contágio como esse marcasse com freqüência o próprio espaço de tantos discursos públicos, especialmente na mídia?

Eis então o que o professor Judt diz para explicar o silêncio, culposo, a seu ver, de Sartre e Foucault: "Intellectuals, so prominent in post-war France, might have been expected to force the issue. Yet people like Jean-Paul Sartre and Michel Foucault were curiously silent. One reason was their near-obsession with Communism. While proclaiming the need to 'engage', to take a stand, two generations of intellectuals avoided any ethical issue that could not advance or, in some cases, retard the Marxist cause".

Tais declarações podem parecer apenas um tanto confusas e vagas, sobretudo quando se trata da causa marxista no caso de Foucault. Depois do subtítulo 
"Shame of the intellectuals" - cuja responsabilidade deve pelo menos dividir com o próprio jornal, o que muitas vezes, infelizmente, somos obrigados a fazer quando devemos escrever em jornais -, o professor-jornalista denuncia a atitude vergonhosa de intelectuais vindos após Sartre e que adotaram um silêncio culposo diante da culpabilidade da França de Vichy e de seus "crimes contra a humanidade": "No one stood up to cry 'J'accuse!' at hight functionaries, as Emile Zola did during the Dreyfus affais. When Simone de Beauvoir, Roland Barthes and Jacques Derrida entered the public arena, it usually involved a crisis for away - in Madagascar, Vietnam or Cambodia. Even today, politically engaged writers call for action in Bosnia but intervene sporadically in debates about the French past".

Mesmo que eu esteja disposto a conceder uma parte de verdade à acusação, devo declarar que, quanto ao fundamental, ela me indignou, e não apenas, peço-lhes que acreditem nisso, por dizer respeito também a mim, pessoalmente, e por ser eu, junto com outros, alvo de uma verdadeira calúnia. Não é a primeira vez que jornais, cujos títulos incluem o nome de New York, dizem não importa o que e mentem de forma caracterizada a meu respeito durante meses e em várias séries de números. Mas se eu fiquei especialmente chocado pelo que em francês chamamos de contre-périté, não foi por essa razão apenas nem simplesmente por ser eu - assim como outros - um daqueles que se preocupam, segundo os termos do professor Judt, com o French past. Antes de tudo é porque, junto com outros, mais de uma vez marquei posição publicamente a respeito deste e também de outros problemas (a Argélia, por exemplo) e, também junto com outros, assinei uma carta aberta ao presidente Mitterand, pedindo-lhe que reconhecesse o que Chirac acabou de reconhecer. Após a leitura do New York Times, desanimado de antemão como lamentavelmente já acontecera muitas vezes, desisti de responder e corrigir essa contre-périté que se tornara verdade pela força conjunta da suposta autoridade de um perito acadêmico e de um jornal com difusão maciça e internacional (americana e européia, pois o mesmo artigo foi reproduzido tal qual na edição européia do International Herald Tribune). Felizmente, quatro dias depois a contre-périté era denunciada no mesmo jornal por outro professor americano, que não conheço, mas à competência e honestidade do qual quero prestar uma grata homenagem, Kevin Anderson, Associate Professor of Sociology na Norther Illinois University, professor em nível mais modesto, numa universidade menos famosa. O New York Times foi então obrigado a publicar uma carta de Kevin Anderson "to the editor" com o título de French intellectuals wanted truth told. Como sempre, a carta é publicada em lugar discreto e, às vezes, impossível de ser encontrado, enquanto o efeito de verdade ou, antes, de contre-vérité do primeiro artigo propriamente dito permanece indelével para milhões de leitores e sobretudo para os leitores europeus do International Herald Tribune que provavelmente nunca terão a oportunidade de tomar conhecimento da dita carta. Kevin Anderson critica, em mais de um 
ponto, a análise política do professor Judt (permito-me remetê-los a essa mesma carta) e precisa, em especial, o seguinte: "On June 15, 1992, a petition signed by more than 200 mainly leftist intellectuals, including Mr. Derrida, Régis Debray, Cornelius Castoriadis, Mr. Lacouture and Nathalie Sarraute, noted that the French occupation government in 1942 acted 'on its own authority, and without being asked to do so by the German occupier.' It called on Mr Mitterand to 'recognize and proclaim that the French state of Vichy was responsible for persecutions and crimes agains the Jews of France."

Pelo que eu sei, mas não sei tudo, e ainda não é tarde demais para aprender, o professor Judt não reconheceu publicamente que não dissera a verdade. Puderam notar que, ao falar do que chamamos em francês contre-périté do artigo do professor Judt, nunca disse que ele tivesse mentido. Nem toda afirmação incorreta pode ser qualificada de mentira. Mentira não é erro. Platão e Agostinho já insistiam, em coro, neste ponto. Se o conceito de mentira tem alguma especificidade resistente, deve ser rigorosamente distinguido do erro, da ignorância, do preconceito, da falta de raciocínio e até da deficiência na ordem do saber, ou ainda - e aí as coisas vão se complicar para nós - da deficiência na ordem da ação ou do fazer, da prática e da tecnologia. Se a mentira não é nem a deficiência do saber ou do saber-fazer, nem o erro, se implica má vontade ou má fé na ordem da razão moral, não da prática, mas da razão pura e prática, se se dirige mais à crença do que ao conhecimento, então o projeto de uma história da mentira não deveria se parecer com nada daquilo que se poderia chamar, segundo Nietzsche em Crepuisculo dos idolos, a história de um erro (Geschichte eines Irrtums).

Seria preciso, sem dúvida, guardar o devido sentido das proporções. Mas como calcular uma proporção quando o poder capitalístico-tecnológico da mídia, no caso um jornal internacional, é capaz de produzir efeitos de verdade, ou de contre-périté mundial, por vezes persistentes e indeléveis, sobre os mais graves assuntos da história da humanidade, muito além das modestas pessoas envolvidas no exemplo recente que acabei de expor? Com as devidas proporções, portanto, a história que narrei não seria nem a história de um erro nem a história de uma mentira. Para mentir, no sentido estrito e clássico do conceito, é preciso saber a verdade e deformá-la intencionalmente. É preciso então mentir a si mesmo. Estou convicto de que se o professor Judt tivesse conhecimento claro e distinto, consciência atual de que os intelectuais, que ele acusa, haviam assinado a carta dirigida a Mitterand, não teria escrito o que escreveu. Acho razoável darlhe esse crédito de confiança: ele não mentiu no sentido próprio da palavra. Não quis clara e deliberadamente enganar, aproveitando-se da confiança ou da crença do leitor. Será que isso implica, da parte dele, apenas erro ou falta de informação? Nisso também não acredito. Se o professor Judt não procurou saber mais a esse respeito, foi também por estar com pressa de chegar a uma conclusão e, portanto, de produzir um efeito de verdade que confirmasse a qualquer preço 
suas teses gerais sobre os intelectuais franceses e a política, tais como as podemos conhecer em seus demais escritos: não sou o único a julgá-las simplistas, como seria possível demonstrar se esse fosse o tema da conferência e o tempo suficiente para tanto. Queria salientar aqui é que a contre-périté não pertence à categoria da mentira nem à da ignorância ou do erro, provavelmente nem mesmo à da mentira a si mesmo, da qual fala Hannah Arendt, não se deixa reduzir a qualquer das categorias legadas pelo pensamento tradicional sobre a mentira - desde Platão e Agostinho até Kant e, até mesmo Hannah Arendt, apesar de todas as diferenças que separam entre si esses pensadores. Pois, aqui está a hipótese que gostaria de submeter à discussão: o conceito de mentira a si mesmo, de engano a si mesmo, do qual Hannah Arendt tem uma necessidade essencial para marcar a especificidade da mentira moderna enquanto mentira absoluta, é também um conceito irredutível àquilo que se chama, com todo o rigor clássico, uma mentira. Mas o que chamo aqui apressadamente de rigor clássico do conceito de mentira tem, ele também, uma história da qual somos os herdeiros e que, em todo caso, ocupa um lugar dominante em nossa cultura e linguagem comum. A mentira a si mesmo não é a má fé nem no sentido comum nem no que Sartre lhe dá. Ela, portanto, necessita de outro nome, de outra lógica, de outras palavras, requer que sejam levadas em conta, a um só tempo, certa tecnoperformatividade da mídia e uma lógica do phántasma (isto é, do espectral) ou uma sintomatologia do inconsciente para as quais a obra de Hannah Arendt acena, mas que ela nunca desenvolve como tal ao que me parece. Temos em Verdade e politica (Truth and politics) vários sinais de que tal conceito de mentira a si mesmo cumpre um papel determinante na análise arendtiana da mentira moderna. É verdade que para ilustrar a mentira a si mesmo Arendt vai buscar exemplos em anedotas e discursos de outros séculos. Sabe-se, há muito tempo, observa ela, que é difícil mentir aos outros sem mentir a si mesmo; e "quanto mais sucesso consegue o mentiroso, mais probabilidade há de que seja vítima das próprias invenções” (12). Mas é sobretudo à modernidade que ela atribui tal possibilidade, inferindo uma conseqüência muito paradoxal a respeito da própria democracia, como se esse regime ideal fosse também aquele em que o enganar estivesse propriamente destinado a se tornar o enganar a si mesmo. Arendt reconhece então uma "força inegável" nos argumentos dos "críticos conservadores da democracia de massa": "Politicamente, o importante é que a arte moderna do 'enganar a si mesmo' seja capaz de transformar um problema exterior em questão interior, de tal maneira que um conflito entre nações ou grupos volta na cena interior. Os enganos a si mesmo praticados pelos dois lados durante o período da Guerra Fria são tão numerosos que não podem ser citados, mas evidentemente são casos especiais. Os críticos conservadores da democracia de massa salientaram freqüentemente os perigos que tal forma de governo introduz nos assuntos internacionais - sem, entretanto, mencionar os perigos particulares às monarquias ou oligarquias. A força de seus ar- 
gumentos está no fato inegável de que, em condições plenamente democráticas, o ‘enganar' que não inclua o ‘enganar a si mesmo' é quase impossível” (13).

Deixo suspensa a questão capital, porém muito difícil, daquilo que se pode entender por condições plenamente democráticas.

Não sei se Hannah Arendt leu ou teve conhecimento de um artigo escrito por Alexandre Koyré, mas deve-se à verdade dizer que as teses arendtianas que acabamos de citar estão exatamente na mesma linha de pensamento desse autor. O texto, publicado em Nova York em 1943 em Renaissance, revista da École Libre des Hautes Études, com o título de Réfléxions sur le mensonge foi republicado em junho de 1945 em Contemporary Jewish Record, sob o título de The political function of the modern lie. $\mathrm{O}$ artigo acabou por ser republicado, na França, pelo Collège International de Philosophie (14). Começa assim: "Nunca se mentiu tanto quanto em nossos dias. Nunca se mentiu de forma mais descarada, sistemática e constante." Nele se encontram os temas arendtianos, em particular o da mentira a si mesmo: "É incontestável que o homem sempre mentiu. Sempre mentiu a si mesmo. E aos outros"; e o da mentira moderna: "É à mentira moderna e, mais estritamente ainda, à mentira política moderna que gostaríamos sobretudo de consagrar algumas reflexões (...) Permanecemos convictos de que, nesse campo quo nibil antiquius, a época atual ou mais exatamente os regimes totalitários inovaram poderosamente (...) O homem moderno - é ainda no homem totalitário que estamos pensando - está mergulhado na mentira, respira a mentira, está submetido à mentira em todos os instantes de sua vida."

Koyré levanta também uma questão que, infelizmente, não desenvolve, pelo menos na direção que hoje me pareceria necessária; pois Koyré se pergunta - o que Arendt não faz - se tem ainda "o direito de falar aqui de mentira".

Não podemos seguir de perto a resposta que Koyré esboça para essa pergunta e me permito por isso remetê-los ao texto original, limitando-me a marcar aqui, de forma esquemática, na estratégia da resposta, as implicações e a textura de uma dificuldade filosófica, que é também ética, jurídica e política. Haverá como utilizar sua resposta caso se tente escrever uma história da mentira e uma genealogia do conceito de mentira, assim como, aliás, desta veracidade sacral, desta heiligkeit do salvo, do são (e santo) ou do incólume que sempre ligou o ético ao religioso?

Na estratégia de Koyré, à necessidade e à força da qual quero em primeiro lugar prestar homenagem, eu me inclinaria a reconhecer a um só tempo um limite e uma abertura. 


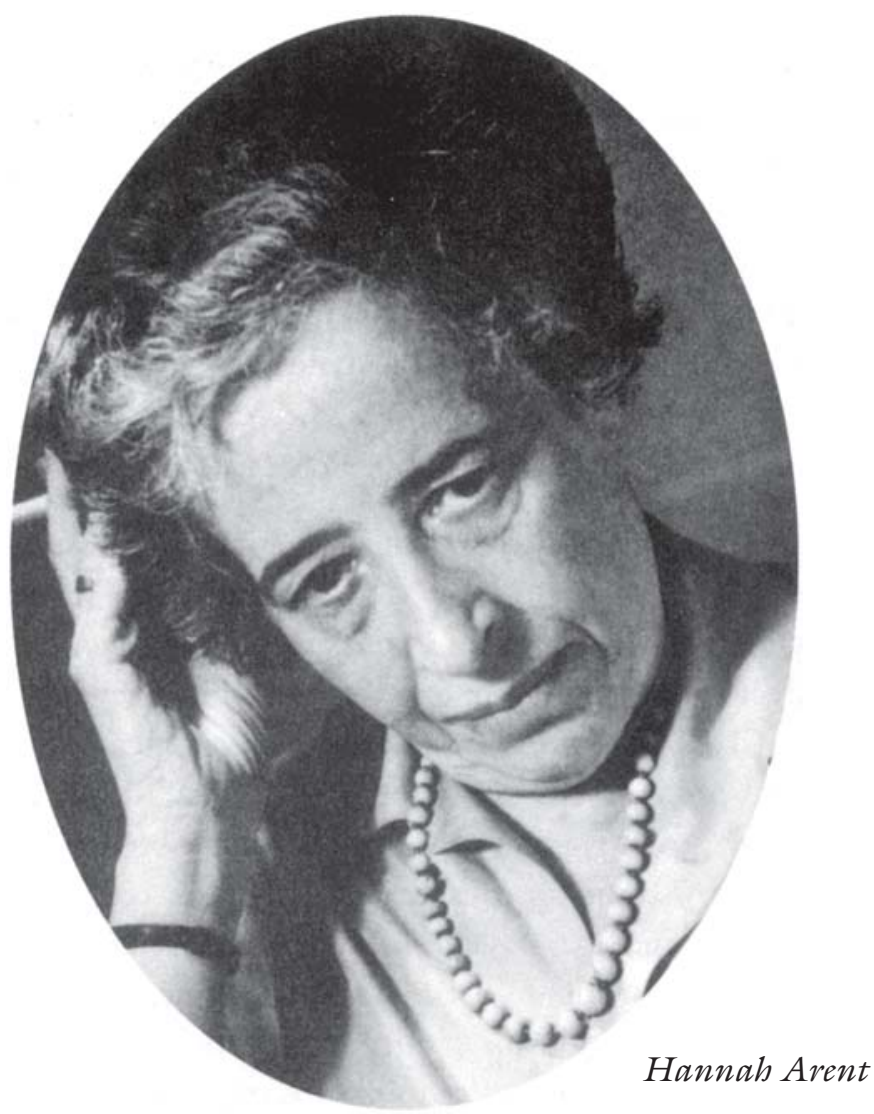

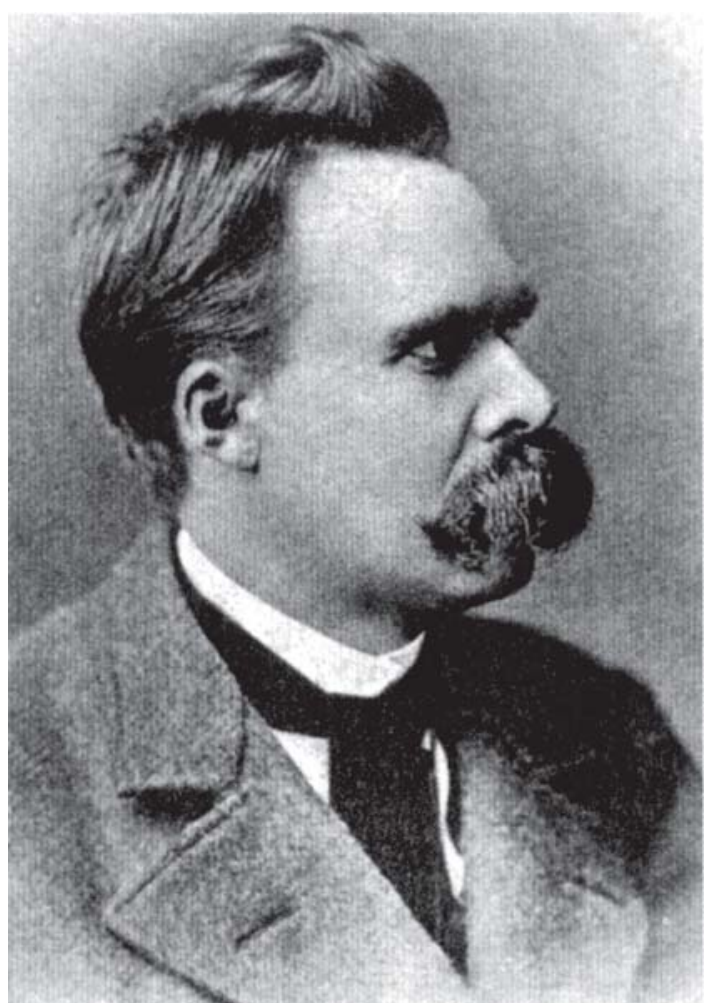

Friedrich Nietzche

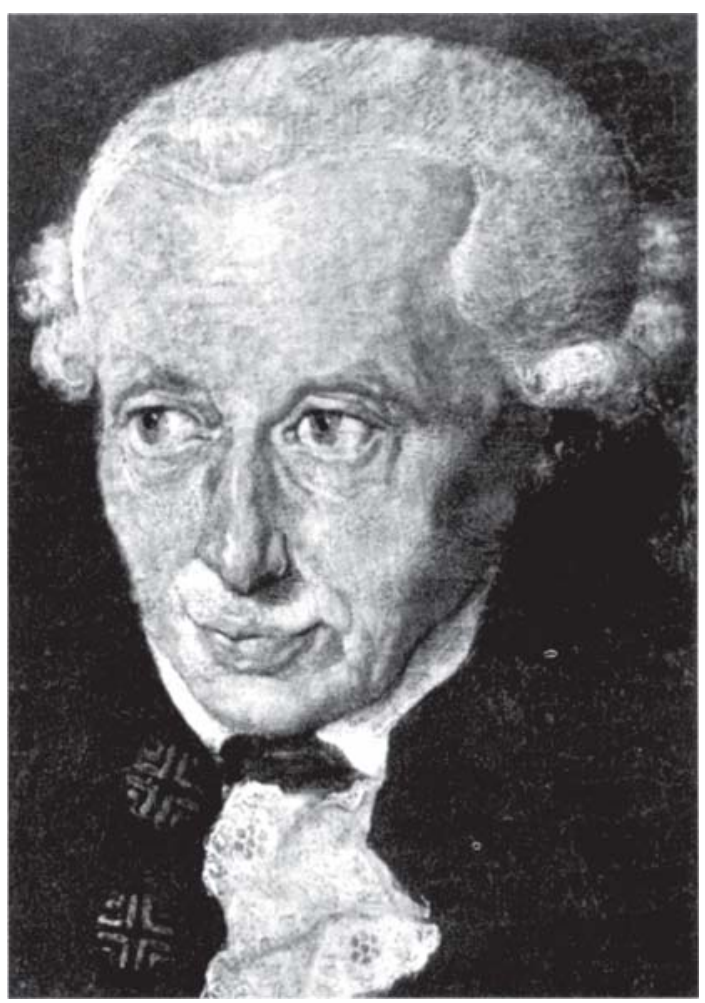

Emmanuel Kant 
Primeiramente o limite, pois Koyré parece suspeitar de qualquer pergunta sobre o direito de recorrer à palavra mentira. Insinua pelo menos que tal pergunta pode ser, já enquanto pergunta, o início de uma perversão totalitária. Ele não está errado, não está totalmente errado. $\mathrm{O}$ risco existe de fato e permanece terrível. Caberá, porém, interrogar-se sobre tal risco. Não haveria outra forma de tratá-lo, levando-se sempre em conta, sem relativismo, situações históricas singulares e novas, sobretudo, introduzindo na análise das situações conceitos que parecem estruturalmente excluídos tanto por Koyré quanto por Arendt, e já antes deles por Kant, Agostinho e Platão, por razões essenciais?

Koyré lembra em primeiro lugar, com toda a razão e mesmo bom senso, que a noção de mentira pressupõe a de veracidade da qual é o oposto ou a negação, da mesma forma que a noção de falso supõe a de verdadeiro. Ele acrescenta então uma advertência pertinente e grave, que nunca deveria ser esquecida, sobretudo em política, mas que nunca nos deveria deter na genealogia desconstrutora do conceito de mentira e, portanto, da veracidade. Tal genealogia tão necessária para a memória e a lucidez crítica, mas também para as responsabilidades que ficam por assumir no presente e no futuro, como fazer para que nem por isso ela acabe arruinando, desacreditando simplesmente aquilo que analisa? Como conduzir uma história desconstrutora da oposição entre veracidade e mentira sem desacreditá-la e sem abrir caminho para todas as perversões contra as quais Koyré e Arendt terão sempre razão de nos prevenir?

Eis, portanto, a advertência de Koyré. Foi escrita em 1943, não nos esqueçamos disso, e vale tanto para aquilo que acontecia naquela época, como para o que aconteceu depois e se desenvolve em nossos dias; pois, o que ele diagnostica sobre as práticas totalitárias de então (para nós, foi ontem) poderia se estender amplamente a certas práticas atuais de supostas democracias, na era de certa hegemonia capitalístico-tecnológica da mídia. "Ora, as filosofias oficiais dos regimes totalitários proclamam de modo unânime que a concepção da verdade objetiva, uma para todos, não faz sentido algum e o critério da 'Verdade' não é seu valor universal (mais adiante, Koyré lembra que existe em Mein Kampf uma teoria da mentira e que os leitores desse livro não entenderam que se tratava deles), mas antes sua conformidade com o espírito da raça, da nação ou da classe, sua utilidade racial, nacional ou social. Prolongando e levando até o fim as teorias biologistas, pragmatistas, ativistas da verdade e consumando assim o que se chamou acertadamente de 'a traição dos clérigos' " , as filosofias oficiais dos regimes totalitários negam o valor próprio do pensamento, o qual para eles não é uma luz, mas uma arma; a sua meta, a sua função, dizem, não é a de nos revelar o real,

* La trabison des clercs, Julien Benda, 1927, advertência dirigida aos intelectuais franceses por um de seus pares: "Os homens, cuja função é a defesa dos valores eternos e desinteressados, como a justiça e a razão, e a que chamo de clérigos, traíram sua função em benefício de interesses práticos.” Les Cahiers rouges, Grasset, 1995. (N. Do T.) 
ou seja, aquilo que é, mas a de nos ajudar a modificá-lo, a transformá-lo, guiando-nos em direção àquilo que não é. Para tanto, como já foi reconhecido há muito tempo, o mito é freqüentemente preferível à ciência, e a retórica que se dirige às paixões, preferível à demonstração que se dirige à inteligência (15).

Repito e insisto, para evitar qualquer mal-entendido: o que diz aqui Koyré parece-me verdadeiro, justo, necessário. Devemos antes de tudo subscrevê-lo. O perigo que ele denuncia sempre deverá ser vigiado com uma diligência sem falha. Entretanto, como puderam ouvir, o que ele condena, muito além do biologismo e das filosofias oficiais do totalitarismo, são todas as interpretações chamadas por ele "pragmatistas ou ativistas" da verdade, o que pode ir mais longe. A suspeita pode atingir tudo aquilo que ultrapassar, por mais de um lado, a determinação da verdade como objetividade ou como tema de um enunciado constativo, até mesmo como adequação e, no limite, qualquer consideração de enunciados performativos. Em outros termos, a mesma suspeita atingiria qualquer problemática que delimitasse, questionasse ou a fortiori desconstruísse a autoridade da verdade como objetividade ou até mesmo como revelação (aletheia). A mesma suspeita atingiria qualquer problemática que levasse em conta, por exemplo, no campo da coisa pública, política ou retórico-tecnológico da mídia, a possibilidade de linguagens instituidoras e performativas (inclusive o testemunho - ato que sempre implica promessa ou juramento performativo). Tal problemática, tão necessária, e para o melhor e para o pior, correria, portanto, o risco de ser antecipadamente desqualificada ou paralisada.

Ressalto aqui duas precauções igualmente necessárias: por um lado, não digo isto para afastar a suspeita formulada por Koyré: mais uma vez, ela é indispensável e legítima, e deve vigiar essas novas problemáticas, por mais urgentes que sejam. Por outro, é verdade também que as mesmas novas problemáticas (do tipo pragmático-desconstrutivo) podem servir a interesses contraditórios. É preciso que essa dupla possibilidade permaneça aberta, ao mesmo tempo como chance e ameaça, sem o que estaríamos apenas assistindo ao desdobramento irresponsável de uma máquina programática. A responsabilidade ética, jurídica ou política, caso haja, consiste em decidir sobre a orientação estratégica que deve ser dada a essa problemática que permanece uma problemática interpretativa e ativa, em todo caso performativa, para a qual a verdade, da mesma forma que a realidade, não é um objeto dado antecipadamente, sobre o qual se trataria apenas de refletir adequadamente. É uma problemática do testemunho, em oposição à prova, que me parece aqui necessária, mas que não tenho condição de desenvolver (digo também, muito rapidamente, por não ter tempo de me estender mais, que uso aqui, com muita facilidade, a palavra performativo, deixando de levantar questões já formuladas em outras oportunidades sobre a oposição performativo/ constativo, seus paradoxos e sobretudo os limites de sua pertinência e pureza. Austin foi o primeiro a nos prevenir contra uma pretensa "pureza" (16) e assim 
eu não iria, ainda menos opondo-me a ele, tentar restaurá-la ou fazer de forma apressada que se acredite nela novamente).

Esse seria, a meu ver, um dos limites da tese de Koyré no artigo em questão. O mesmo limite, acredito, encontra-se em Arendt. Mas Koyré esboça um passo além de tal limite, numa direção em que eu gostaria de ter avançado. De fato, Koyré sugere que os regimes totalitários e os que a eles se assemelham de uma forma ou de outra, nunca se arriscaram para além da distinção entre verdade e mentira - distinção oposicional e tradicional - por terem dela uma necessidade vital, pois é dentro dela que mentem e, por isso, têm interesse em mantê-la intacta e em sua forma mais dogmática a fim de pôr em prática o enganar. Apenas, conforme a velha axiomática metafísica, eles concedem a primazia à mentira, limitando-se assim à simples inversão da hierarquia, inversão com a qual Nietzsche, no fim da História de um erro (e em outros lugares), diz que não podemos nos satisfazer.

Citemos ainda longo trecho de Koyré: "Assim, em suas publicações (mesmo naquelas que se dizem científicas), em seus discursos e, evidentemente, em sua propaganda, os representantes dos regimes totalitários pouco se importam com a verdade objetiva. Mais poderosos que o próprio Deus Todo-Poderoso, transformam a seu bel-prazer o presente e até o passado [é pela 'reescritura' do passado histórico que superam o próprio Deus, o qual seria incapaz de mudar o passado: em 1943, sob o regime de Vichy, Koyré evoca 'o ensinamento histórico dos regimes totalitários' e também 'os novos manuais de História das escolas francesas']. Disso poder-se-ia concluir - e isso já ocorreu algumas vezes - que os regimes totalitários 'situam-se além da verdade e da mentira'. Acreditamos, por nossa parte, que não é nada disso. A distinção entre verdade e mentira, imaginário e real, permanece válida mesmo dentro das concepções e regimes totalitários. O lugar e o papel de tais conceitos é que, de certa forma, foram invertidos: os regimes totalitários baseiam-se na primazia da mentira" (é de Koyré o grifo das últimas palavras) (17).

Essa primazia da mentira num sistema totalitário (confessado ou não), o qual, mais do que qualquer outro, precisa de uma crença na oposição estável e metafisicamente assegurada entre veracidade e mentira, Koyré não encontrou na época, dificuldade alguma para ilustrá-la; não teríamos também qualquer dificuldade em fazer o mesmo hoje, com exemplos próximos ou longe de nós. Por definição, o mentiroso é alguém afirmando que está dizendo a verdade (essa é uma lei de estrutura e sem história); quanto mais, porém, uma máquina política mente, mais ela faz do amor à verdade uma palavra de ordem de sua retórica "Odeio a mentira", é uma declaração célebre do marechal Pétain, como o lembra Koyré. Gostaria, por minha parte, de comentar outro slogan do tempo de 
Vichy com sua ideologia reacionária do "Retorno à terra" *, como lugar seguro dos valores da família e da pátria: "A terra não mente", dizia outro slogan da época.

Entre as perspectivas abertas por essas páginas de Koyré, seria preciso, a meu ver, privilegiar pelo menos duas delas e deixar suspensa a elas uma grave questão.

- A primeira abertura diz respeito à perversão paradoxal que consiste em mentir no segundo grau: "técnica maquiavélica das piores", diz Koyré, arte na qual Hitler tinha se tornado perito e se resumia em dizer a verdade sabendo que não seria levado a sério pelos desavisados, numa espécie de "conspiração em plena luz do dia", da qual Hannah Arendt falará também freqüentemente como da forma da mentira moderna. Dizer a verdade com o fim de enganar aqueles que crêem que não devem crer nela. Koyré não fora - tampouco Freud, aliás - o primeiro a identificar tal astúcia, mas manifesta a preocupação de interpretá-la como técnica política moderna na época das comunicações de massa e do totalitarismo.

- A segunda perspectiva do artigo se abre para uma teoria do segredo. Esse é, na realidade, o tema fundamental e mais insistente do artigo: não o tema da "sociedade secreta", mas o de uma "sociedade de segredos", cuja estrutura possibilita uma "conspiração em plena luz do dia" que não seja uma contradição in adjecto.

É o•desenvolvimento muito original de tal teoria do segredo político que poderia inspirar preocupação, a respeito do qual direi apenas poucas palavras: parece que Koyré considera que todo segredo é em princípio uma ameaça à res publica, na realidade ao espaço democrático. Entendo sua posição, consoante com certa essência da politeia como fenomenalidade absoluta, mas me pergunto se não estamos vislumbrando aqui o anúncio da perversão oposta, a de um politismo, de uma absolutização do político, de uma extensão sem limite da área do político. Recusando então qualquer direito ao segredo, o poder político intima a todos, primeiro de tudo e em tudo, que se comportem como cidadãos responsáveis perante a lei da polis. Não haveria nisso, em nome de determinado tipo de verdade objetiva e fenomenal, outra semente de totalitarismo com aparência democrática? Não li sem algum estupor indignado uma observação de Koyré que, para ilustrar o treinamento para o segredo, o críptico e a mentira, acusava, sem diferenciá-los, o espartano, o índio, o jesuíta e o marrano: "Citemos ao acaso o treinamento para a mentira do jovem espartano e do jovem índio, a mentalidade do marrano e do jesuíta".

" Retorno à terra, “a terra não mente”, outros lemas de Vichy, com duas motivações, uma ideológica, outra prática (a escassez de alimentos). (N. Do T.) 
Se, contra o fenomenalismo e o politismo integral, nos ativéssemos a um direito incondicional ao segredo e tal segredo absoluto devesse permanecer inacessível e invulnerável, ele não concerniria ao segredo político, mas, antes, à figura metonímia do marrano, ao direito ao segredo enquanto direito à resistência contra a ordem do político, até mesmo do teológico-político em geral e para além dessa ordem; e, na política, o mesmo direito poderia inspirar, como a uma de suas figuras, o direito que os Estados Unidos, em caso de força maior e quando a razão de Estado já não representa a última palavra da ética, designam, pela belíssima palavra de civil desobedience, a mais respeitável de suas tradições.

Devo, ainda por falta de tempo, acelerar a conclusão desses prolegômenos e voltar a Hannah Arendt. Há realmente a possibilidade de uma história da mentira enquanto tal? Estou menos seguro disso do que nunca. Mas caso se tentasse tal empreendimento, seria preciso levar em consideração toda a obra de Hannah Arendt e mais precisamente, nos ensaios que eu citei, dois conjuntos de quatro motivos dos quais uns parecem propícios e outros desfavoráveis a tal projeto.

Concluindo, portanto, eis a seguir um programa e uma dupla de quatro mensagens telegráficas. A seguir. os motivos propícios a tal história da mentira:

- O cuidado claramente expresso (18) de subtrair essa história à predicação moral. Um pouco como Nietzsche, de modo análogo e ao mesmo tempo diferente, Arendt pretendia tratar diversas questões num sentido extramoral.

- A consideração não apenas do desenvolvimento da mídia, mas de uma nova estrutura da mídia que veio transformar o estatuto do substituto icônico da imagem (19) e do espaço público (temática ausente do discurso de Koyré).

- A intenção evidente de delimitar a ordem do político, de cercá-lo de fronteiras teóricas, práticas, sociais e institucionais (fronteiras em princípio muito estritas, apesar de, como é fácil imaginar, ficarem difíceis de ser traçadas, por razões não contingentes). O que se dá em duas direções: por um lado, destacando que o homem, na sua "singularidade", na "verdade filosófica" de sua individualidade solitária é "não-político por natureza" (20); por outro lado, atribuindo à ordem do Judiciário e da Universidade, virtualmente independente do político, missões novas e responsabilidades capitais nessa delimitação da mentira política (21).

- Esboçar, sem usar a palavra e sem desenvolver suficiente ou determinantemente, uma problemática da performatividade de uma mentira cuja estrutura e cujo acontecer estariam ligados de forma essencial ao conceito de ação e mais especialmente da ação política (22). 
Hannah Arendt lembra freqüentemente que o mentiroso é, ousarei dizer, um homem de ação por excelência. Entre mentir e agir, agir em política, manifestar a própria liberdade pela ação, transformar os fatos, antecipar o futuro há como uma afinidade essencial. Segundo Arendt, a imaginação é a raiz comum à "capacidade de mentir" e à "capacidade de agir". Capacidade da imagem em produzir: imaginação produtora como experiência do tempo, teriam dito Kant ou Hegel. A mentira é o futuro, podemos nos arriscar a dizer para além da letra, mas sem trair a intenção de Arendt nesse contexto. Ao contrário, dizer a verdade é dizer aquilo que é ou terá sido, antes seria dizer o passado. Mesmo insistindo em marcar-lhe os limites, Arendt fala de uma "afinidade inegável da mentira com a ação, com a mudança do mundo, ou seja, com a política". O mentiroso, diz ela, não precisa de acomodações para "aparecer na cena política"; tem ele a grande vantagem de estar sempre, por assim dizer, exatamente no centro dela. Ele é ator por natureza; diz o que não é porque quer que as coisas sejam diferentes daquilo que são; em outras palavras, "ele quer mudar o mundo (...) Em outros termos, nossa capacidade de mentir - mas não necessariamente nossa capacidade de dizer a verdade - faz parte de alguns dos dados manifestos e demonstráveis que confirmam a existência da liberdade humana" (23).

Mas se tais enunciados requerem algumas modalizações devem ser corrigidos por determinado coeficiente de possibilidade (tradução que não temos tempo de fazer agora), é claro que não temos apenas aqui, esclarecida por Hannah Arendt, a idéia de uma história da mentira, mas, também, com radicalidade maior, a tese segundo a qual não existiria história em geral nem história política em particular sem ao menos a possibilidade do mentir, isto é, da liberdade e da ação. Assim como a da imaginação e a do tempo, da imaginação tanto quanto do tempo.

Em que o discurso arendtiano fecha ou corre o risco de fechar o que ele abre dessa forma? É o que precisaria ser evocado para concluir ou pelo menos encerrar nossos tímidos prolegômenos.

Em contrapartida, quatro motivos me parecem ter desempenhado um papel inibidor, se não proibidor, na tentativa de levar a sério semelhante história.

- A ausência de uma verdadeira problemática do testemunho ou da atestação (testimony, witnessing and bearing witness). Arendt não se interessa pela história de tal conceito, tampouco daquilo que o distingue absolutamente da prova ou do arquivo, mesmo que, na realidade e de forma não fortuita, um equívoco venha sempre confundir o limite entre tais possibilidades radicalmente heterogêneas. A distinção entre "verdade de fato" e "verdade racional", que forma o arcabouço de todo esse discurso, parece ser aqui insuficiente. Arendt reconhece ter recorrido à distinção apenas provisoriamente e por comodidade (24). Cita, mais de uma 
vez, o testemunho (25), mas não faz dele o verdadeiro tema de uma análise eidética; tampouco o faz para a mentira nem aliás para a fé ou a boa fé. Koyré procede da mesma forma. Ambos fazem como se soubessem o que quer dizer mentir.

- O que precede não está desligado do conceito de "mentir a si mesmo" ou de "auto-sugestão" (26), que cumpre um papel determinante em todas as demonstrações de Arendt. Tal conceito permanece confuso na psicologia por ele implicada. Permanece também logicamente incompatível com o rigor de qualquer conceito clássico da mentira. Mentir sempre há de querer dizer enganar intencional e conscientemente o outro, sabendo aquilo que se esconde deliberadamente, sem, portanto, mentir a si mesmo. Se pelo menos a palavra si tem algum sentido, o si exclui o mentir a si mesmo. Outra experiência, qualquer que seja, requer então outro nome e procede provavelmente de outra zona ou estrutura, digamos para abreviar, da intersubjetividade ou da relação ao outro, o outro em si, numa ipseidade mais originária do que o ego (individual ou coletivo), uma ipseidade de encraves, uma ipseidade divisível ou clivada. Não direi que a psicanálise ou a analítica do Dasein (dois discursos que não se regulam a princípio por uma teoria do ego ou do eu) são as únicas capazes de medir-se com esses fenômenos chamados por Arendt mentir a si mesmo ou auto-sugestão; mas Arendt, como Koyré, no momento em que ambos falam necessariamente de mentira a si mesmo em política, fazem aparentemente tudo para evitar qualquer alusão a Freud e Heidegger sobre tais problemas. Será fortuito?

- O que parece comprometer o projeto de uma tal história da mentira, ou pelo menos sua irredutível especificidade, é um otimismo indefectível, o qual não pertence à ordem da psicologia. Ele não reflete em primeiro lugar uma disposição pessoal, um hábito ou um ser-no-mundo, nem mesmo um projeto de Hannah Arendt. Afinal, falar de nosso tempo como da idade da mentira absoluta, procurar se dar os meios de analisálo com implacável lucidez não é demonstrar otimismo. Otimista, antes, seria o dispositivo conceitual e problemático que aqui se encontra estabelecido ou credenciado. Está em jogo a determinação da mentira política, mas também, antes de tudo, a da verdade em geral, a qual sempre deve triunfar e acabar por se revelar pois, em sua estrutura, como repete freqüentemente Arendt, a verdade é estabilidade assegurada, irreversibilidade; ela sobrevive indefinidamente às mentiras, ficções e imagens (27). Tal determinação clássica da verdade, como sobrevivência indefinida do estável (bebaion, diriam Platão e Aristóteles) (28), não parece simplesmente suscitar grande número de questões desconstrutivas (e não apenas no estilo heideggeriano). Ao excluir até a possibilidade de 
uma mentira sobreviver indefinidamente, ela não vai somente contra a própria experiência; ela faz da história, como história da mentira, o acidente epidérmico e epifenomenal de uma parúsia da verdade. Ora, uma história específica da própria mentira deveria passar, pelo menos, pela história da cristianização (em Paulo, em alguns Padres da Igreja, em Agostinho e seu De mendacio etc.), da temática grega do pseudos (que quer dizer a uma só vez o falso, o fictício e o mentiroso, o que não simplifica ou simplifica demais as coisas), do eidolon e do phántasma espectral, da retórica, da sofística e da mentira politicamente útil, segundo A Repúbliva de Platão (29), da mentira útil, curativa ou preventiva como phármakon. Essa cristianização radical encontra-se em estado secularizado, e na Idade das Luzes, se é que se pode dizer assim, na doutrina kantiana que condena a mentira como decadência absoluta, "vício capital da natureza humana", "negação da dignidade humana": "o homem que não acredita naquilo que diz é menos do que uma coisa", diz Kant em sua Doutrina da virtude (30). A não ser, teríamos vontade de responder, que deixe então de ser menos do que uma coisa para se tornar alguma coisa ou até alguém, já algo como um homem.

- Eis porque, finalmente, podemos sempre nos preocupar com a secundarização, a relativização ou acidentalização, até mesmo banalização de uma teoria ou história da mentira, enquanto continuasse dominada pela certeza arendtiana de uma vitória final e de uma sobrevivência assegurada da verdade (e não apenas da veracidade) sobre a mentira, ainda que se lhe aceite a teleologia apenas como justa idéia reguladora em política ou na história do socius humano em geral. Não se trata aqui, para mim, de opor a esse risco a hipótese judeo-cristiano-kantiana da mentira como mal radical e sinal da corrupção originária da existência humana, mas de marcar que sem ao menos a possibilidade dessa perversão radical e de sua sobrevivência infinita, sem a consideração em particular de mutações tecnológicas na história e na estrutura do simulacro ou do substituto icônico, sempre fracassaremos na tentativa de pensar a mentira em si mesma, a possibilidade de sua história, a possibilidade de uma história que a envolva intrinsecamente e, provavelmente, a possibilidade de uma história tout court.

Mas é preciso confessar, para acelerar a conclusão, que nada nem ninguém poderá jamais comprovar, justamente, o que se chama propriamente comprovar, no sentido estrito do saber, da demonstração teórica e do juízo determinante, a existência e a necessidade de uma história como essa enquanto história da mentira.

Apenas se pode dizer aquilo que poderia ou deveria ser a história da mentira, se é que ela existe. 
Notas

l "Dizer uma coisa falsa não é mentira se alguém crê verdadeiro ou se tem opinião formada de que é verdadeiro aquilo que diz (si credit aut opinatur verum esse quod dicit). A crença, aliás, difere da opinião. Aquele que crê sente por vezes que ignora aquilo que é objeto de sua crença, sem por isso duvidar da verdade desta, por ser ele muito firme em sua fé. Aquele que formou uma opinião sobre algo pensa saber o que ignora. Ora, quem enuncia um fato que lhe parece digno de crença ou acerca do qual emite a opinião de que é verdadeiro não mente, mesmo que o fato seja falso (etiamsi falsum sit)", Santo Agostinho, Le mensonge (De mendacio), Primeira parte, $1^{a}$ seção, 111, 3, trad. fr. G. Combes, em Oeuvres de Saint Augustin, Paris, 1937-1948, T. 2, p. 237.

2 Op. cit., p. 244-246.

3 Id. De outra maneira o Hippias menor de Platão levava também em conta a possibilidade de alguém dizer a verdade querendo mentir, ou não mentir dizendo o falso (367 a).

4 Truth and politics, tr. fr. Vérité et politique, por Cl. Dupont e A. Hurant, em La Crise de la Culture, Idées Gallimard, 1972, p. 289-290.

5 Lying in politics, reflections on the Pentagon Papers, em Crisis of the Republic, New York, 1972, p. 4-5.

6 Vérité et politique, p. 425-325.

7 Id. ibid., p. 321

8 Hannah Arendt, Truth and politics, em Between past and future: eight exercises in political thought, New York, The Viking Press, 1968, p. 252-253 e ss.

9 Reiner Schürmann, Le principe d'anarchie, Heidegger et la question de l'agir, Ed. du Seuil, 1982, p. 183-184, n. 1.

10 Kant, Uber ein vermeintes Recht aus Menschensliebe zu lügen.

11 Jean-Pierre Chevènement, Vichy, laver ou noyer la honte?, Liberation, 7 ago. 1995.

12 Vérité et politique, p. 323.

13 Id., ibid., p. 326.

14 Alexandre Koyré, La fonction politique du mensonge moderne, em Rue Descartes 8/ 9, Collège International de Philosophie, Paris, Albin Michel, nov. 1993.

15 Id. ibid., p. 180-181.

16 Austin, How to do things with words, Décima-Segunda Conferência, p. 150, tr. fr. p. 152. Se se pudesse entrar aqui em pormenores, seria preciso analisar de perto as 
distinções austinianas entre, por exemplo, uma promessa de má fé com intenção de não a cumprir, e uma mentira. Uma promessa de má fé permanece uma promessa efetiva, "não é, porém, uma mentira nem uma afirmação falha" (Primeira Conferência, p. 11, tr. fr. p. 45).

17 Koyré, cit., p. 181.

18 "É uma velha e complicada história, a do conflito entre verdade e política, e a simplificação ou a predicação moral não ajudariam em nada". Vérité et politique, cit., p. 292.

19 Cf. supra, p. 13 Imagem é a palavra-chave ou o conceito maior de todas as análises consagradas à mentira política de nosso tempo (imagens fabricadas, imagem mentirosa, imagem de propaganda, imagem versus acontecimento, imagem definitivamente mistificadora etc. (Ibid. p. 325-326 et passim). A palavra e o conceito de imagem prestam-se aqui à confusão. A análise de tal transformação do ícone foi apenas esboçada por Arendt, ao que me parece. O que está em jogo, e ela não o disse, é uma mutação que afeta o estatuto substitutivo de um substituto. Tende-se a representar e a credenciar tal substituto (alegando-se, por exemplo, o "ao vivo") já não em qualidade de substituto-representante-referente, mas como a coisa-mesma: na própria percepção ele já veio substituir-se à coisa-mesma, a qual, supondo-se que tenha existido como tal, desaparece então para sempre, sem que ninguém se preocupe em reclamá-la ou em requerer-lhe a diferença. Sem falar da focalização, da seleção, da interpretação e de todas as intervenções agora tecnicamente possíveis, em fração de segundo, entre a gravação e sua reprodução-difusão.

20 Vérité et politique, cit., p. 313: "Considerar a política na perspectiva da verdade, como fiz aqui, quer dizer, estabelecer-se fora do campo político" (p. 330) "A posição fora do campo político - fora da comunidade à qual pertencemos e da companhia de nossos pares - é claramente caracterizada como sendo um dos diversos modos do ser só. Eminentes entre os modos existenciais do dizer-a-verdade, são a solidão do filósofo, o isolamento do sábio e do artista, a imparcialidade do historiador e do juiz e a independência do descobridor de fatos, da testemunha, do repórter (Tal imparcialidade (...) não é adquirida dentro do campo político, mas é inerente à posição de forasteiro requerida por ocupações desse tipo)" (p. 331) "É totalmente natural que seja apenas em caso de conflito que tomemos consciência da natureza não-política e virtualmente antipolítica da verdade - Fiat veritas et pereat mundus: até agora enfatizei esse aspecto da questão" (p. 331).

21 Ibid.p. 332.

22 Motivo muito presente desde as primeiras páginas de Lying in politics, reflections on the Pentagon Papers. Por exemplo: "A characteristic of human action is that it always begins something new, and this does not mean that it is ever permitted to start ab ovo, to create ex nibilo. In order to make room for one's own action, something that was there before must be removed or destroyed, and things as they were before are changed. Such change would be impossible if we could not mentally remove ourselves from 
where we physically are located and imagine that things might as well be different from what they actually are. In order words, the deliberate denial of factual truth the ability to lie - and the capacity to change facts - the ability to act - are interconnected; they owe their existence to the same source: imagination" (p. 5). É preciso, naturalmente, relacionar o conceito organizador da imaginação com o discurso sobre a "imagem" de que falamos antes.

23 Vérité et politique, cit. p. 319.

24 Id., ibid., p. 305 e ss.

25 Id., Ibid., p. 303, 310.

26 Lying in politics, IV, tr. fr., em Du mensonge à la violence (Agora, Pocket), p. 39-4047. Vérité et politique, cit., p. 296, 324.

27 “Id., ibid., cit., p. 328-329. Por exemplo: "As imagens nunca podem rivalizar em estabilidade com aquilo que é, simplesmente porque é assim mesmo e não de outra forma" (p. 328), ou então outra proposta mais otimista ainda: "O poder, pela própria natureza, jamais pode produzir um substituto para a estabilidade assegurada da realidade factual, porque ela já passou, cresceu até uma dimensão fora de nosso alcance. Os fatos afirmam-se por si mesmos, por sua obstinação, e neles a fragilidade secombina surpreendentemente com uma grande resistência à torção irreversibilidade essa que é o cunho de toda ação humana" (p. 329). Em Lying in politics, Arendt escrevia com valente otimismo: "no matter how the tissue of falsehood than an experienced liar has to offer, it will never be large enough, even if enlists the help of computers, to cover the immensity of factuality" (p. 7 et passim). Mas, supondo, concesso non dato, que se subscreva a determinados enunciados quando dizem respeito a fatos do tipo "foi a Alemanha que invadiu a Bélgica no mês de agosto de 1914", exemplo a que se prende muito Arendt, como continuar subscrevendo os fatos quando eles já são fenômenos de discurso performativo próprio da mídia, estruturados pelo simulacro ou o virtual e que incorporam o próprio momento interpretativo? Permanece, em verdade, a questão de saber como determinar a estrutura do substituto e, no nosso caso, da imagem na informação e narração de hoje. O substituto-imagem continuava referindo-se à própria coisa - é sua função substituíla - e até à verdade de sua revelação. Como já observamos (ver nota 19), o substituto do simulacro moderno (o ao vivo na televisão, por exemplo) toma o lugar daquilo que substitui e, por sua performatividade seletiva e interpretativa, pelo efeito de verdade absoluta e indubitável que produz, destrói até a referência à alteridade daquilo que substitui. Temos aqui, provavelmente, o lugar de uma mentira absoluta que sempre pode sobreviver indefinidamente sem que pessoa alguma jamais tenha sabido de tal mentira, ou sem que haja mais ninguém para saber ou lembrar-se dela. Sempre pode, talvez, mas é preciso manter esse regime do talvez e essa cláusula de possibilidade, se quisermos evitar ainda dissolver a história da mentira numa história da verdade, num saber teórico e sob a autoridade de juízos determinantes.

28 Sobre a questão do bebaios como valor de estabilidade e confiabilidade, fundada na 
estabilidade, de fiaestabilidade, permito-me remetê-los à Politiques de l'amitié, Galilée, 1994 (passim).

29 Numa nota de Vérité et politique (n. 5, tr. fr. p. 376), Hannah Arendt alude, é verdade, a uma passagem crucial (414c) da República. Ela lembra justamente que pseudos pode significar em grego ficção, erro ou mentira, conforme o contexto. Mas, além de nunca mencionar, que eu saiba, esse tratado explícito da mentira que é o Hippias menor, não há certeza de que haja contexto algum que tenha decibilidade bastante para se tornar decisivo, que seja determinável bastante para levar à determinação do sentido.

30 Citado em rico artigo de Michèle Sinapi, ao qual pretendo voltar em outra oportunidade, Le mensonge officieux dans la correspondance Jérôme-Augustin, em Rue Descartes $8 / 9$, cit. Através dessa correspondência, a autora do artigo analisa o cruzamento de duas tradições heterogêneas, a de uma "concepção da palavra apoiada numa ontologia imaginal" e a do "direito romano", da ciência do processo, de uma nova elaboração de noções de prova e de causa (p. 65).

Jacques Derrida, filósofo, é professor da École Pratique des Hautes Etudes en Sciences Sociales da Universidade de Paris e ex-professor da École Normale Supérieure. Tornou-se internacionalmente conhecido pelos livros L'ecriture et la différence e De la grammatologie, ambos traduzidos no Brasil. A partir de então publicou, entre outras obras, $L a$ dissémination (1972), La vérité en peinture (1978), Mémoires-Pour Paul de Man (1986), Heidegger et la question (1987), Le droit à la philosophie (1990), Spectres de Marx (1993), Politiques de l'amitié (1994), Apories e Résistance de la psychanalyse (1996).

Conferência feita pelo autor no Auditório do Museu de Arte de São Paulo (Masp) em 4 de dezembro de 1995. O evento foi organizado pelo Núcleo de Pesquisa Brasil-França (Nupebraf) do Instituto de Estudos Avançados da USP, Departamento de Filosofia da FFLCH-USP e pela Pontifícia Universidade Católica de São Paulo (PUC-SP), com o apoio da Folba de S. Paulo.

Tradução de Jean Briant. Preparação de Hermínia Antonia G. Bernardini. Revisão de Leyla Perrone-Moisés. O original em francês - Histoire du mensonge: prolégomènes encontra-se à disposição do leitor no IEA-USP para eventual consulta. 